\title{
Islam, Religion, Practice, Culture and World Order
}

\author{
Imtiyaz Yusuf, ed.
}

Herndon, VA: The International Institute of Islamic Thought, 2012. 96 pages.

Isma'il al-Faruqi (1921-86), a reformer, a visionary, and a great modern scholar, wrote on several aspects of Islam and Muslim interactions with major spiritual traditions of the world. This short book is a collection of his brief reflections on Islam's basic ideals. Thus it is not a research work, but rather an explication on how Islam should be comprehended on its own merit. Expressed in simple language to make its contents accessible to the general public and containing no references, it consists of seven parts each comprised of three or four chapters. The arrangement of topics was not chronological, even though one would have expected its editor, Imtiyaz Yusuf - one of al-Faruqi's students - to pay attention to such order by rearranging the chapters. For ex- 
ample, one would logically expect the discussion of the $i s r \bar{a}$ ' and $m i$ ' $r \bar{a} j$ to come before the discussion of the hijrah.

In part 1, al-Faruqi eloquently defines who is a Muslim, what Islam is, and why a Muslim is a Muslim. He surveys the Muslim world before 1980 and Arabic's role as a universal language for all Muslims. His description of Islam and Muslims fits well with the seven dimensions of religion proposed by Ninian Smart, a pioneer in the field of secular religious studies, given that al-Faruqi looks at Islam from its theological, cultural, social, practical, material, legal, and phenomenological perspectives. To him, Islam is a universal religion practiced by a diverse community.

Membership in this universal community is open to all people, for its only prerequisite is the individual's readiness to recognize God's oneness (tawhìd) by verbalizing the profession of faith (shahädah), after which they become a Muslim and enjoy all of the rights and privileges conferred by Islam. Now an honored human being, as opposed to a sinner, their salvation depends upon their faith and doing of good deeds. While al-Faruqi insists that "deeds alone" guarantee salvation (p. 6), other Muslim scholars argue that salvation is based on faith and action (ìmān and 'amal). Yet, a "true" Muslim, al-Faruqi affirms, is one who competes in righteous deeds, one who strives to be God's representative on Earth (khalīfat Allāh) (p. 8).

Al-Faruqi also dispells Christianity's negative portrayal of humanity. Islam, in his reading, portrays humanity as a wholly positive creature, one that is neither fallen nor damned, for those who sin and thereafter sincerely seek forgiveness will find themselves pardoned by God. Islam denies the core Christian belief that God had to ransom humanity by sacrificing Jesus. Such a view, al-Faruqi contends, attributes violence to God and to humanity. Islam is a world-affirming (not a world-denying) religion, and thus humanity prepares for the next life by engaging in good deeds.

Further, al-Faruqi states that Islam is not a new religion but only the continuation of earlier monotheistic religions. It became a universal religion in the seventh century when Muhammad reintroduced, purified, and applied it. Upon the Prophet's death, his followers began to spread Islam to their neighbors and beyond. People from different nations lived under it peacefully for seven centuries, drawn to Islam because the Muslims practiced what they preached. Muslims did not hesitate to marry non-Muslim women and to pursue knowledge and wisdom from non-Muslim individuals and civilizations.

In chapters 5 to 9, al-Faruqi explicates Islam's five pillars: the shahādah, salat , sawm, zakat, and hajj. He elaborates upon the true meanings of shahadah and how it is "the foundation" of Islam. He defines salāt as worship rather than prayer, for it connects Muslims with God; it is a spiritual discipline. Noth- 
ing draws a Muslim nearer to God than prostration. Al-Faruqi renders zakat as "wealth sharing" rather than "charity," for the former strengthens the relationship between the giver and the recipient by neutralizing the absence of envy that often arises between the poor and the rich. Zakat is a bond of humanity, fellowship, and communal unity. Sawm, a communion with divinity, is a deeply personal affair because only God knows who fasts and determines its reward. This practice is a form of self-discipline and training in the art of resistance, one that cultivates among those who observe it the qualities of patience, forbearance, and steadfastness. Importantly, it also enables one to commiserate with and acquire a more accurate understanding of the reality faced by the hungry, the poor, and the deprived.

Al-Faruqi perceives hajj as a lesson of self-denial, a conscious act of putting an end to one's human-derived status before God by making oneself equal to everybody else. Whatever distinguishes a person from another is dismantled during this event. The huge gathering of pilgrims at 'Arafah has no parallel in any other religion. After this chapter comes an account of the Muslims' unconditional love for Prophet Muhammad, whose name is mentioned and blessed several times daily by every Muslim. When he died, his Companions carried the Qur'an to other peoples. And because he was "the good exemplar" for all humanity, his life was recorded, taught, and emulated.

In the next chapter, al-Faruqi talks about the birth of the Islamic ummah, which began with the Prophet's emigration to Madinah. This event constitutes the birth of a new world order, for from his new base Muhammad launched Islam as neither an Arab nor a tribal movement, but as a world movement. The following chapter relates the $i s r \bar{a}$ ' and $m i$ ' $r \bar{a} j$ to Muhammad's connection to the Jewish and Christian prophets and affirms that Islam is a continuation of these two religions. Through this event, Islam recognizes Judaism and Christianity as monotheistic and legitimate religions in their origin.

The next chapter features al-Faruqi's affirmation that women are positively good (as opposed to evil) by nature, equal to men, have legal rights that are clearly mandated in the Qur'an, and that both genders are garments to one another. Islam, therefore, totally rejects the claim that women are responsible for humanity's fall from heaven. According to the Islamic account of creation, men and women were created to live on Earth. Both sinned, sought forgiveness, and were pardoned by God (Q. 2:36). Nevertheless, each gender has its distinctive obligations and rights.

Islam encourages marriage and considers extramarital sex to be immoral and an act of societal violence. As marriage is regarded as a legal contract, both parties enter into it of their own free consent and can dissolve it whenever they want. Islam also allows polygyny (when necessary) to meet the societal 
needs; however, men who choose such a lifestyle must meet specific conditions related to their equal and fair treatment of all wives, especially in the areas of love and kindness. Al-Faruqi argues that the home is the best base for a wife, but that she is free to pursue her own carrier as long as doing so does not negatively affect her ability to raise the couple's children.

Part 5, which deals with Muslim workers, focuses on two issues: humanity's stewardship of nature and wealth. As each human being is God's representative, each person has been tasked with making Earth a peaceful and livable place for all creatures. God made nature subservient to humanity, who discovers its secret and benefits from them. Nature cannot be destroyed, but it can be changed and modified to serve humanity. Al-Faruqi also dwells upon Islam's view of wealth creation and its preference for a market economic system. All forces of nature, human labor, and accumulated scientific knowledge should be employed and exploited to create and produce wealth without causing harm to others (p. 72). Therefore Islam prohibits interest, gambling, cheating, and hoarding, in addition to instituting a fair distribution of wealth by means of zakat and sadaqah.

Toward the end of the book, the articles focus on the Islamic community's unity, a society in which everyone perceives others as brothers and sisters because they are all human and therefore equal subjects and objects of the same moral law. Hence, they should all strive to excel in good deeds. Al-Faruqi points out that citizenship in an Islamic state is open to anyone who agrees to live under the auspices of Islam's moral law and that Muslims are forbidden to force Islam upon non-Muslims. He further argues that Islam has a unique culture, one distinguished by its use of arabesque and calligraphy, its architectural and artistic styles and norms, and Qur'anic recitation.

In the last chapter, al-Faruqi briefly surveys the history of Islam and Muslims. Islamic history, which he considers the history of all monotheistic revelations, comprises the contributions of Islam and Muslims to civilization from the seventh century onward, none of which can be ignored or underrated. Yet when the Muslims abandoned their revelation and strayed from the right path, they lost their glory, witnessed the downfall of their empires, and became prey to the colonial powers of the West and East. Al-Faruqi strongly believes that this lost glory could be regained if Muslims were to return to their pristine message and practice Islam, as well as abandon Sufism on the grounds that it robs them of their ingenuity. 